\title{
Geoelectric Investigation of Aquifer Vulnerability within Afe Babalola University, Ado -Ekiti, Southwestern Nigeria.
}

\author{
O.S. Ogungbemi ${ }^{1}$, G.O. Badmus ${ }^{2}$, O.G. Ayeni ${ }^{3}$, O. Ologe ${ }^{4}$ \\ ${ }^{I}$ Department of Chemical/Petroleum Engineering, Afe Babalola University, Ado Ekiti, Nigeria. \\ ${ }^{2}$ Department of Physics, Afe Babalola University, Ado Ekiti, Nigeria. \\ ${ }^{3}$ Department of Physics, Federal University, Oye Ekiti, Ekiti State, Nigeria. \\ ${ }^{4}$ Department of Chemical/Geological Sciences, Al-Hikmah University, Ilorin, Nigeria.
}

\begin{abstract}
Many investigation techniques are commonly employed with the aim of estimating the spatial distribution of transmissivity and protective capacity of groundwater resources. Unfortunately, the conventional methods for the determination of hydraulic parameters such as pumping tests, permeameter measurements and grain size analysis are intrusive and relatively expensive. A non-intrusive and less-expensive geoelectric investigation involving vertical electrical sounding was carried out in some parts of the campus of Afe Babalola University, Ado Ekiti, Ekiti State, Nigeria. A total of fifty-nine (59) vertical electrical sounding (VES) data were acquired using $R 50$ D.C. resistivity meter within the campus which is underlain by the Precambrian basement rock of southwestern Nigeria. Following the interpretation of the VES data, maps and 2D-sections were generated. The geoelectric sections enabled the subsurface to be characterized into five geoelectric layers namely: Topsoil, clayey/sandy-clay, weathered layer, fractured basement and fresh basement. The assessment and analysis of the materials above the aquifers showed that longitudinal conductance (S) values ranged from 0.08438 to 0.73449 mhos; thus the area is classified into weak $(0.1-0.19$ mhos $)$, moderate $(0.2-0.69$ mhos $)$ and good protective capacity (0.7 mhos and above). The major aquifer delineated is the weathered/fractured basement aquifers. These aquifers are characterized by thick overburden, moderate/good protective capacity, moderate to relatively high value coefficients of anisotropy and low transverse unit resistance. This suggests that the materials above the aquifers act as seal, thus protecting the major aquiferous units. However, the aquifer matrix itself is relatively permeable. Areas with weak protective capacity are therefore vulnerable to infiltration of polluting fluid.
\end{abstract}

Key words: Aquifer, basement, geoelectric, overburden, vertical electrical sounding.

\section{Introduction}

Groundwater exploration within the basement complex rocks of Africa is usually carried out with the use of Vertical Electrical sounding (VES) [1]. This is because the successful exploitation of basement terrain groundwater requires a detailed understanding of the hydrogeological characteristics of the aquifer units viz-aviz its susceptibility to environmental pollution. This is particularly important in view of the localized nature of the basement aquifers [2]. The most probable use of the electrical resistivity survey is in hydrogeological investigation in relation to aquifer delineation, lithologic boundaries and geological structures to provide subsurface information [3]. The method has been used extensively in groundwater investigation in the basement complex terrains [4], [5], and also in the sedimentary basins [6], [7], [8]. Hence, drilling programmes for groundwater development in areas of basement terrain are generally preceded by detailed geophysical investigations. The discontinuous nature of the basement aquifer system makes detailed knowledge of the subsurface geology, its weathering depth and structural disposition through geologic and geophysical investigations inevitable [9].

The study area is underlain by Precambrian basement complex rocks. These rocks are inherently characterized by low porosity and near negligible permeability. The highest groundwater yield in basement terrains is found in areas where thick overburden overlies fractured zones.

\subsection{Study Location and Geology}

The study area is located within Latitude $07^{\circ} 35.986^{\prime}$ and $07^{\circ} 36.522^{\prime} \mathrm{N}$ and Longitude $05^{\circ} 18.110^{\prime}$ and $05^{\circ} 18.626^{\prime} \mathrm{E}$. It is situated directly opposite the Federal Polytechnic Ado-Ekiti, along Ijan-Ekiti road. The topography is approximately flat with elevation ranging from 355 to $374 \mathrm{~m}$ above sea level. Part of the Campus is drained by River Ogbese (Fig. 1). The geology of the study area can be explained within the context of the geology of the Precambrian basement Complex of southwestern Nigeria which form a part of the basement complex of Nigeria [10]. The major rock type within the area is typically migmatite-gneiss comprising of undifferentiated granite, charnockitic rocks, medium to coarse granite and migmatite-gneiss rocks (Fig. 2). The vegetation in the area is of rainforest type, characterized by short dry season and long wet season, with high 
annual rainfall of about $1,300 \mathrm{~mm}$. Annual mean temperature is between 180 and $330^{\circ} \mathrm{C}$ with relatively high humidity [11].

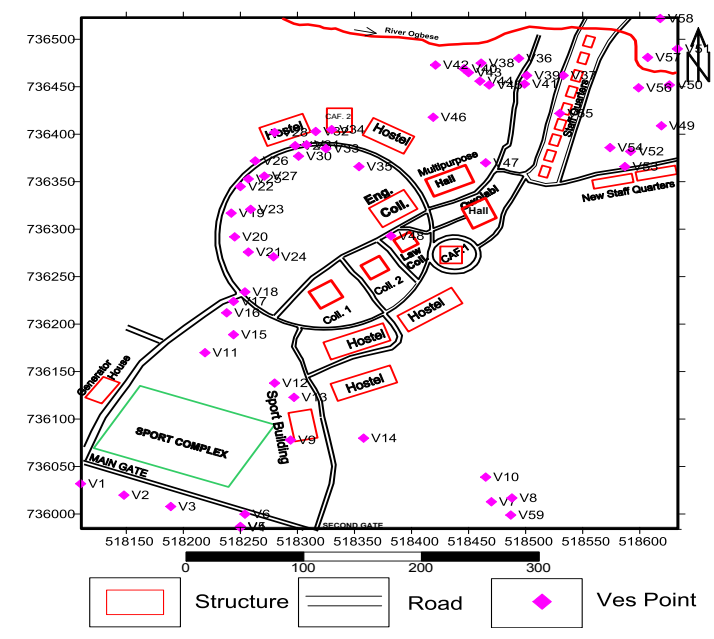

Figure 1: Base map of the study area showing VES points.

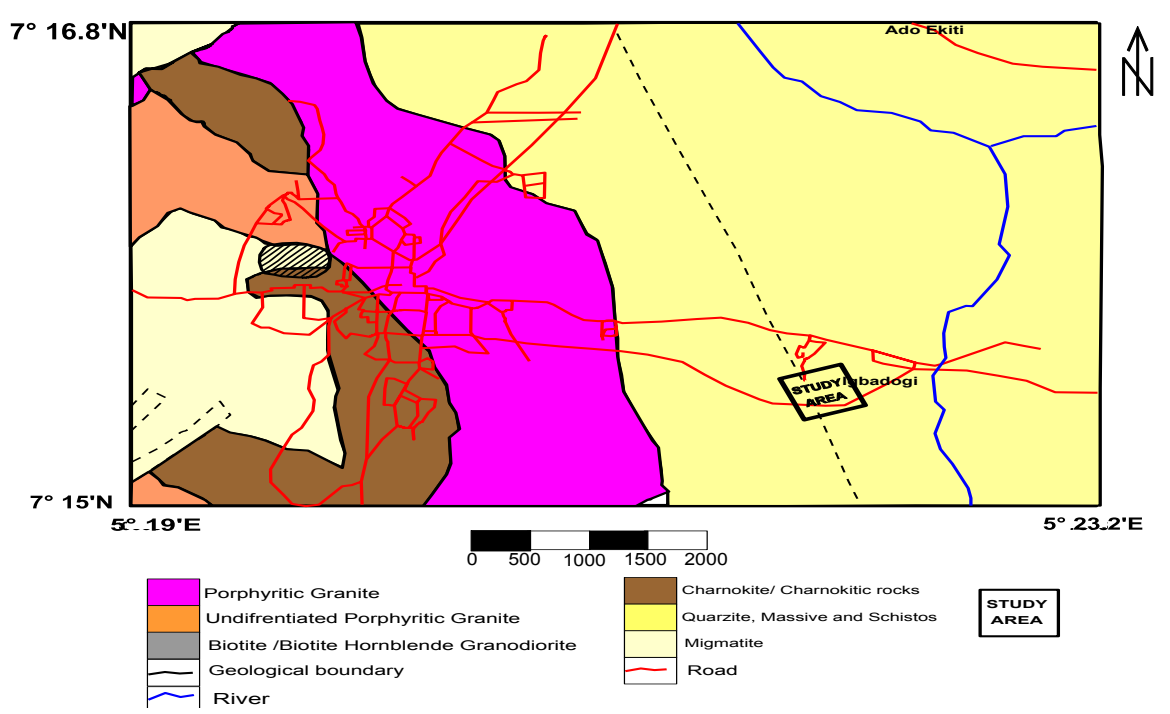

Figure 2: Geological map of Ado Ekiti showing the study area.

\section{Materials and Method of Study}

The geophysical data was acquired with the R-50 D.C. resistivity meter which contains both the transmitter unit, through which current enters the ground and the receiver unit, through which the resultant potential difference is recorded. Other materials include: two metallic current and two potential electrodes, two black coloured connecting cable for current and two red coloured cable for potential electrodes, two reels of calibrated rope, hammer for driving the electrodes in the ground, compass for finding the orientation of the traverses, cutlass for cutting traverses and data sheet for recording the field data. The Schlumberger array was adopted (Fig. 3). The electrode spread of $\mathrm{AB} / 2$ was varied from 1 to a maximum of $150 \mathrm{~m}$. The expected depth of investigation was $(D)=0.125 \mathrm{~L}$, where $\mathrm{L}=\mathrm{AB} / 2$ and $\mathrm{AB}$ the current electrode separation. Sounding data were presented as sounding curves, by plotting apparent resistivity against $A B / 2$ or half the spread length on a bi-log paper. 


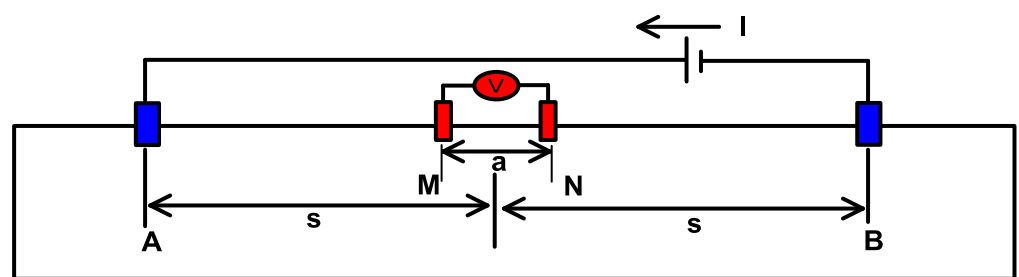

Figure 3: Sketch diagram of Schlumberger array.

The models obtained from the manual curve matching interpretations were used for computer iteration to obtain the true resistivity and thickness of the layers. Computer-generated curves were compared with corresponding field curves by using a computer program "Resist" version 1.0. The software was further used for both computer iteration and modeling. Computer iteration of between $1-29$ were carried out to reduce errors to a desired limit and to improve the goodness of fit [12].

The Dar-Zarrouk parameters are obtained from the first order geoelectric parameters (layer resistivities and thicknesses); these include the Total longitudinal unit conductance (S), Total transverse unit resistance (T), and coefficient of anisotropy $(\lambda)$. These secondary geoelectric parameters are particularly important when they are used to describe a geoelectric section consisting of several layers [13]. For $n$ layers, the total longitudinal unit conductance is:

$$
\begin{aligned}
S & =\sum_{\mathrm{i}=1}^{n}\left(\frac{h_{i}}{\rho_{i}}\right) \\
T & =\sum_{i=1}^{n} \rho_{\mathrm{i}} \mathrm{h}_{\mathrm{i}} \\
\lambda & =\left(\frac{\rho_{T}}{\rho_{L}}\right)^{\frac{1}{2}} \ldots .
\end{aligned}
$$

where $\boldsymbol{h} \boldsymbol{i}$ is the layer thickness, $\boldsymbol{\rho}_{\boldsymbol{i}}$ is layer resistivity while the number of layers from the surface to the top of aquifer, (i) varies from 1 to n. Electrical anisotropy is a measure of the degree of earth's inhomogeneity [14],[15]. In a typical basement terrain, this electrical effect is due to near surface features such as variable degree of weathering and structural features like faults, fractures, joints, foliations and beddings. These in turn are responsible for creating secondary porosity $(\Phi s)$ and effective porosity $(\Phi e)$.

Table 1: Modified longitudinal conductance/protective capacity rating [16].

\begin{tabular}{|l|l|}
\hline $\begin{array}{l}\text { Longitudinal conductance } \\
\text { (mhos) }\end{array}$ & Protective capacity rating \\
\hline$>10$ & Excellent \\
\hline $5-10$ & Very good \\
\hline $0.7-4.9$ & Good \\
\hline $0.2-0.69$ & Moderate \\
\hline $0.1-0.19$ & Weak \\
\hline$<0.1$ & Poor \\
\hline
\end{tabular}

\section{Results and Discussion}

\subsection{Aquifer Protective Capacity Evaluation}

The nature of the materials that overlain the mapped aquifers were evaluated using the layer parameters (i.e. resistivity and thickness), the longitudinal unit conductance $(\mathrm{S})$, the transverse unit resistance $(\mathrm{T})$ and the coefficient of anisotropy $(\mathcal{C})$ to determine its capacity to prevent infiltration of unwanted fluids into the aquifer. It should be noted that the earth materials act as a natural filter to percolating fluids; therefore its ability to retard and filter percolating ground surface polluting fluids is a measure of its protective capacity [17]. That is to say that the geologic materials overlying an aquifer could act as seal in preventing the fluid from percolating into it. The longitudinal unit conductance map (Fig. 4), derived from equation 1 for all the VES locations, was used for the overburden protective capacity rating of the study area. The highly impervious clayey overburden, which is characterized by relatively high longitudinal conductance, offers protection to the underlying aquifer [18]. The longitudinal unit conductance (S) values obtained from the study area, ranges from 0.08438 to 0.73449 mhos. Clayey overburden, which is characterized by relatively high longitudinal conductance, offers protection to the underlying aquifer. According to the classification in Table 1 above, the longitudinal unit conductance values from the study area was used to classify the area into weak, moderate and good protective capacity zones. Where the conductance is greater than 0.7 mhos are considered zones of good protective capacity. The portion 
having conductance values ranging from 0.2 to 0.69 mhos was classified as zone of moderate protective capacity; and area with values ranging from 0.1 to 0.19 mhos were classified as exhibiting weak protective capacity while the zones where the conductance value is less than 0.1 mhos were considered to have poor protective capacity. This work has revealed that the overburden materials in the area around the south-western and north-eastern portions of the study area have good to moderate protective capacity and are relatively thick (between 19 to $33 \mathrm{~m}$ thick). The central and western portions have moderate protective capacity materials with thin overburden (between 6 to $17 \mathrm{~m}$ thick), while the northern, southern, eastern and part of the central region exhibit weak to poor overburden protective capacity and thin overburden thickness. This map (Fig. 5) further reveals that about $60 \%$ of the area falls within the poor/weak overburden protective capacity, while about $40 \%$ constitutes the moderate/good protective capacity rating.

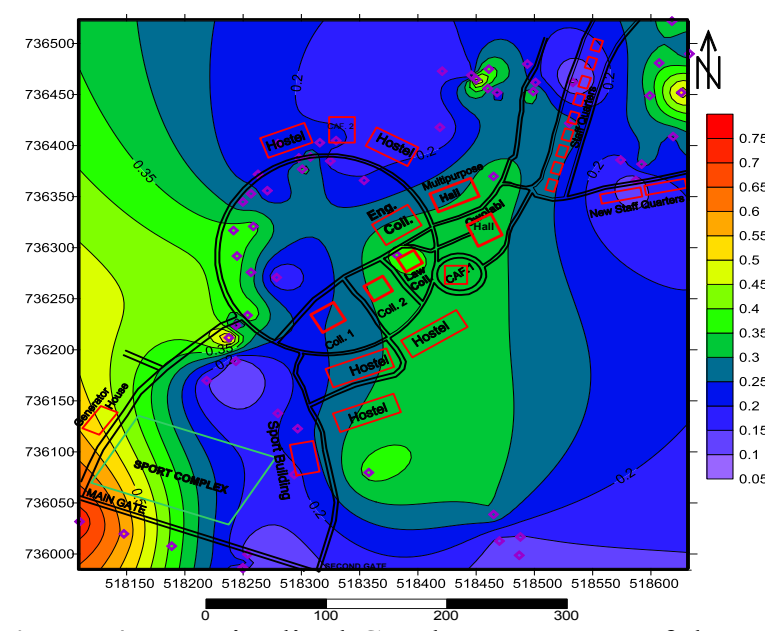

Figure 4: Longitudinal Conductance map of the study area

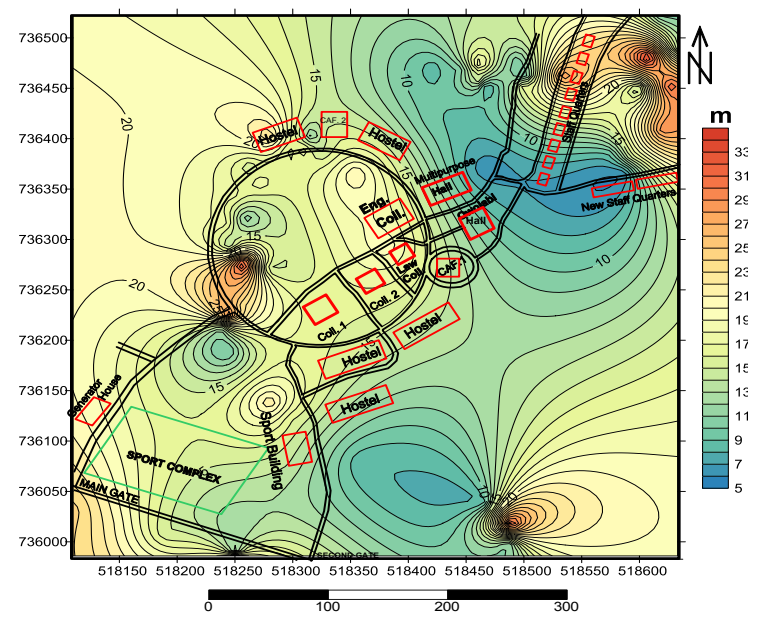

Figure 5: Overburden thickness map of the study area

Fig. 6 is the map of coefficient of anisotropy of the area. The coefficient of anisotropy values $(\lambda)$ ranges from 0.238 to 8.90 . The southern to central part of the study area is characterized by high values of coefficient of anisotropy ranging from 3.5 to 9.0 , while the remaining part is characterized by low values coefficient of anisotropy. This relatively high value of coefficient of anisotropy $(\lambda)$ coincides with shallow basement ridge thus, suggesting that it is due to near surface inhomogeneity of materials within the subsurface such as the topsoil and weathered/partially weathered layer which could not support groundwater development. However, within the basement depression the value of coefficient of anisotropy $(\lambda)$ is generally low, ranging from 0.5 to 2.5. This is arising from variation in the structural features such as fractures, joints, and faults, and is relevant in the groundwater development of the area. The basement ridge at the southern portion is at shallow depth, which may not support groundwater resource development, although the overburden is moderately protected against polluting fluid(s). 


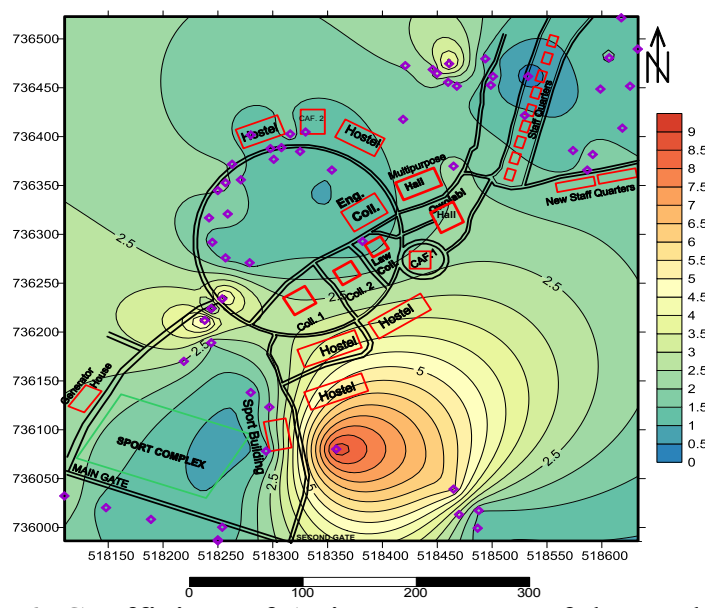

Figure 6: Coefficient of Anisotropy map of the study area.

\subsection{Geo-electric Sections}

The subsurface sequence comprise of the topsoil with limited hydrologic appeal, sandy-clay layer, weathered/fractured basement and the fresh basement. The weathered/fractured layer constituted the sole aquifer unit in the area. The 2-D geoelectric sections $(7 \mathrm{a}-\mathrm{c})$ were drawn in N-S and NW-SE directions.

Fig. 7a has varying topsoil resistivity of $77-256.1 \mathrm{ohm}-\mathrm{m}$ and thickness of 0.5 to $2.0 \mathrm{~m}$. The second lithologic layer corresponds to clayey-sand with layer resistivities of 227 to $699 \mathrm{ohm}-\mathrm{m}$ and thickness of 1.0 to $1.5 \mathrm{~m}$. The third layer is the weathered layer having resistivities of 26.8 to $58.9 \mathrm{ohm}-\mathrm{m}$ and thickness of 5.6 to $14.6 \mathrm{~m}$. There is the presence of fractured/fresh basement with resistivity of about 303.5 to $963.6 \mathrm{ohm}-\mathrm{m}$ and infinite thicknesses. The structural variation showed thickening of the overburden under the VES-Points WC38 and TR25/1, the depth to bedrock is deep around the south-eastern side, while the basement is dipping towards the south-eastern side. The down dip side has the highest depth to bedrock, which is controlled by structural features relevant for groundwater development.

In Fig. 7b, the topsoil resistivity range from 100.7 to $134 \Omega$-m with thickness of about 0.5 to $2.7 \mathrm{~m}$. The second layer has resistivity of 111 to $563.4 \Omega-\mathrm{m}$ and thicknesses range of 1.6 to $2.6 \mathrm{~m}$, which correspond to clay materials. Under TR1/1 the clayey topsoil layer with resistivity of 111 to $563.4 \Omega-\mathrm{m}$. There is the presence of weathered layer with resistivity of 29.8 to $33.9 \Omega-\mathrm{m}$ and thickness of 8.0 to $21.6 \mathrm{~m}$. It is relatively thick under TR1/1 and the area is suspected to have harboured abstractable amount of portable groundwater. Structurally, the basement is depressed towards the NW part and is assumed to be groundwater flow direction. There is the presence of a fractured basement under TR2/1 which is also trending towards the north-western direction.

In Fig. 7c, the topsoil resistivity range from 96.6 to $496 \Omega$-m with thicknesses of about 0.6 to $1.8 \mathrm{~m}$. The second layer, which is the sandy-clay, has resistivity of 233.8 to $466.6 \Omega-\mathrm{m}$ and thicknesses of 1.5 to $2.6 \mathrm{~m}$. The clayey layer underlay the Topsoil only under TR8/1 and TR14/2 across the section. There is the presence of weathered layer with resistivity between 25.3 and $83 \Omega$-m and thicknesses ranging from 0.7 to $16 \mathrm{~m}$. It is thickest under TR11/1 and TR16/2 and the area is favourable to groundwater accumulation and abstraction. Structurally, the basement is depressed towards the NW part and is assumed to be groundwater flow direction. The aquifers mapped in the study area are the weathered/fractured layer (unconfined) and the fractured layer (confined) types.

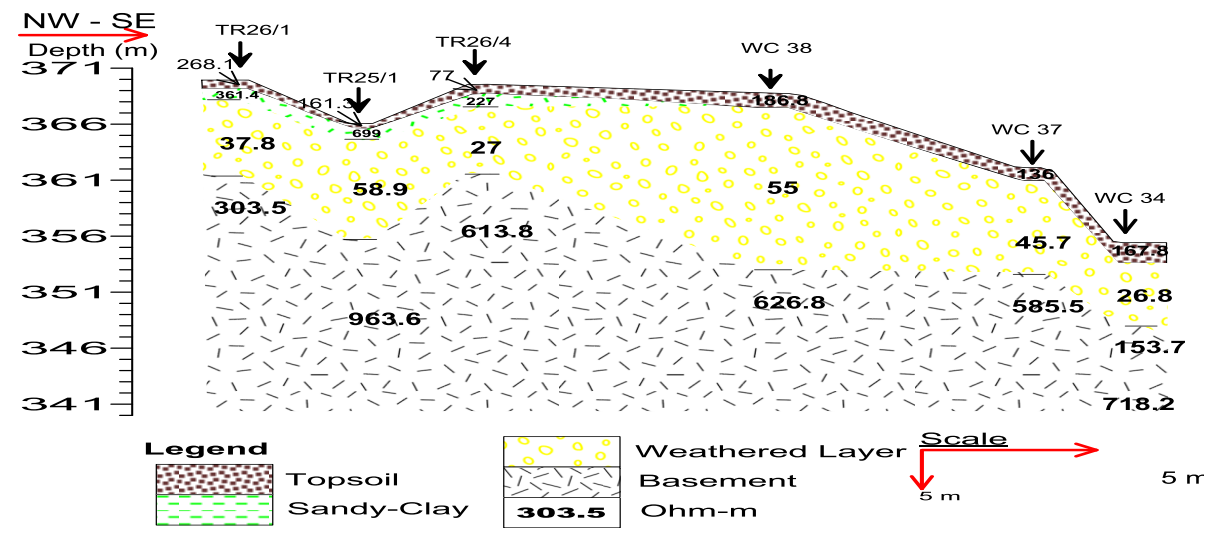

Figure 7a: Geo-electric section cutting across TR25/1, TR26/1, TR26/4, WC38, WC37 and WC34 


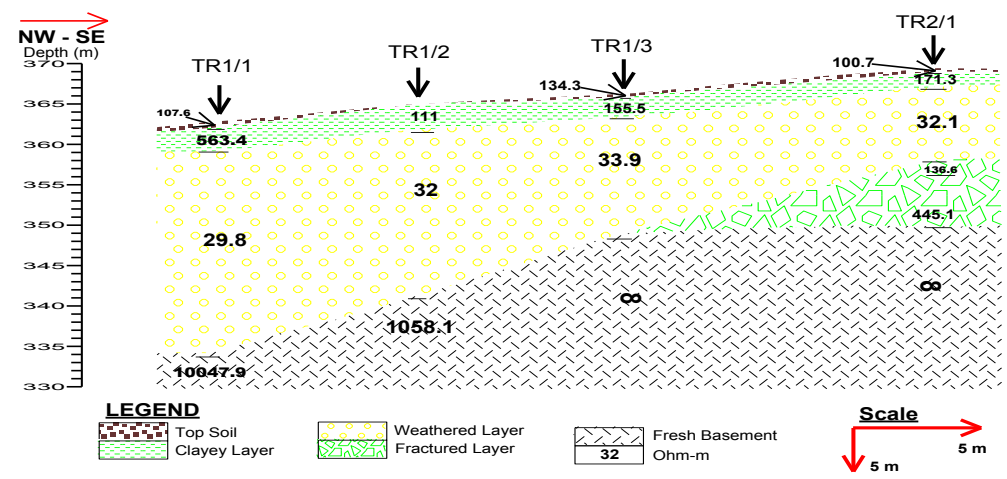

Figure 7b: Geo-electric section along traverse 1 (NW-SE) cutting across TR1/1, TR1/2, TR1/3 and TR2/1

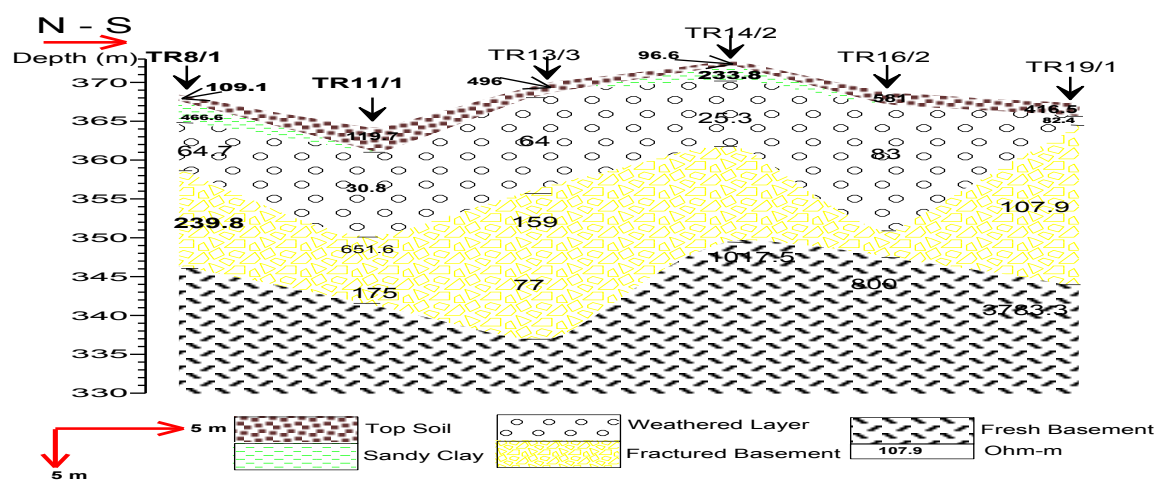

Figure 7c: Geo-electric section cutting across TR8/1, TR11/1, TR13/3, TR14/2, TR16/2 and TR19/1

\section{Conclusion}

In this study, the groundwater transmissivity and protective capacity evaluation of the rock units within Afe Babalola University, Ado-Ekiti, southwestern Nigeria were undertaken using 59 Schlumberger vertical electrical soundings (VES). The geoelectric parameters (layer resisitivity and thickness) at each sounding station were used to produce the overburden thickness map and the geoelectric sections and to also generate the second order parameters (Dar Zarrouk parameters) i.e. the longitudinal unit conductance (S), the transverse unit resistance (R) and the coefficient of anisotropy $(\boldsymbol{K})$ values of the area. Generally, the profiles revealed four to five subsurface layers: the top-soil, sandy-clay/clayey layer, the weathered layer, partially weathered/fractured basement and the fresh basement.

The study revealed that most parts of the area covered are underlain by materials of weak to moderate protective capacity. The central, the southwestern and the western portions of the area are underlain by materials of moderate to good protective capacity. The areas with good to moderate protective capacity coincide with zones of appreciable overburden thickness with clayey columns thick enough to protect the aquifer in the area from the surface polluting fluid. The area with thin overburden also coincided with weak protective capacity thereby exposing the groundwater in the area to polluting fluid. If for example, there is leakage of buried underground storage tanks; this may constitute a serious environmental hazard. Therefore vulnerable zones include the southern, southeastern, eastern and northern region. The area with high values of coefficient of anisotropy and low values of transverse unit resistance which is a reflection of the transmissivity nature of rocks also coincide with relatively thin overburden thickness making the groundwater in the area vulnerable to polluting fluid.

The results of this study have provided reliable information about the protective capacity of the materials overlying the aquiferous unit which must be considered for planning, development and siting of academic, residential and commercial facilities within the central academic and residential area of the campus of Afe Babalola University, Ado Ekiti. For effective groundwater development programmes in the study area, it is recommended that pre-drilling geophysical investigations be carefully conducted for economic and environmental purposes. Future groundwater development in the study area by the management should be concentrated within the zones of moderate/good groundwater protective capacity with appreciably thick overburden. Also, siting of underground petroleum storage tanks, sewage septic tanks and waste dump within the campus should be confined to zones of moderate/good ground water protective capacity. 


\section{Acknowledgements}

The authors would like to acknowledge with gratitude, the efforts of Mr. O.Z. Ajayi, the engineer in charge of the field data acquisition equipment and his crew. Also the assistance of other colleagues both academic and technical is acknowledged with thanks.

\section{References}

[1] G.J. Palacky, Resistivity characteristics of geologic targets: In electromagnetic methods in applied geophysics, M.N Nabighion, Ed., Society of Exploration Geophysicist, Tulsa, OK 1(3), 1988, 53-130.

[2] B.N Satpatty, B.N. Kanugo, Groundwater exploration in hard rock terrain, a Case study, Geophysical Prospecting, 24(4), 1976, 725 $-736$.

[3] K.N Bose, D Chatterjee, A.K Sen, Electrical resistivity surveys for groundwater in the Aurangabad Sub-division, Gaya District, Bihar, Indian, 1973, 171-181.

[4] J.O Barongo, G.J Palacky, Investigations of electrical properties of weathered layers in the Yala area, Western Kenya, using resistivity soundings. Geophysics, 56(O.I), 1991, 133-138.

[5] A.I.Olayinka, M.O. Olorunfemi, Determination of geoelectrical characteristic in Okene area and implication for boreholes setting, $J$. Min. Geol. 28, 1992, $403-412$.

[6] J.H De Beer, J. Blume, Geophysical and hydrogeological investigations of the groundwater resources of western Hereroland, South west Africa/Namibia, Trans. Geol. Soc. S. Africa, 88, 1985, 483-493.

[7] P.D.C. Mbonu, J.O Ebeniro, C.O Ofoegbu, A.S. Ekine, Geoelectric sounding for the determination of aquifer characteristics in parts of the Umuahia area of Nigeria, Geophysics, 56(2), 1991, 284-291.

[8] E.N. Shemang, Groundwater potentials of Kubami River Basin, Zaria, Nigeria, from D.C. Resistivity study. Water Resources, 1(2), $1993,36-41$

[9] K. A. N Adiat, G. M. Olayanju, G. O. Omosuyi and B. D. Ako, Electromagnetic profiling and electrical resistivity soundings in groundwater investigation of a typical basement complex - a case study of Oda town southwestern Nigeria. Ozean Journal of Social Sciences, 2(4), 2009, 333-359.

[10] M.A. Rahaman, Review of the basement geology of southwestern Nigeria: In Geology of Nigeria (Kogbe CA Ed.). Elizabeth Publishing. Co. Nigeria. 1989, 41-58.

[11] Nigeria Meteorological Agency, (NIMET). Daily weather forecast on the Nigerian Television Authority, Nigerian Metrological Agency, Oshodi, Lagos. 2007.

[12] B.P.A. Vander Velpen. "Resist Version 1.0". M.Sc. Research Project. ITC: Delft, Netherlands, 2004

[13] A.A.R. Zohdy, G.I. Eaton and D.R. Mabay, Applications of surface geophysics to groundwater investigation techniques of water resources. Geophysical survey, Washington. 1974.

[14] M.P. Billings, Structural Geology (3rd ed. Englewood Cliffr. NJ: Prentice-Hall 1972).

[15] S.B. Maliek, D.C. Bhattacharya, S.K. Nag, Behavior of fractures in hard rocks - a study by surface geology and radial VES methods. Geoexploration, 21, 1973, 529-556.

[16] M.I. Oladapo, O.J. Akintorinwa, Hydrogeophysical Study of Ogbese Southwestern, Nigeria. Global J. Pure and Applied Sci., 13(1), 2007, 55-61.

[17] M.O. Olorunfemi, J.S. Ojo, O.M Akintunde, Hydrogeophysical evaluation of the groundwater potential of Akure metropolis, southwestern Nigeria. J. Min. Geol., 35(2), 1999, 207-228.

[18] O. Abiola, P.A. Enikanselu, M.I. Oladapo, Groundwater potential and aquifer protective capacity of overburden units in Ado-Ekiti, southwestern Nigeria, International Journal of Physical Sciences, 4(3), 2009, 120-132. 